\title{
Water saving potential in the RBD of Thessaly
}

\author{
NIKOLAOS GOURGOULETIS, GEORGIOS BARIAMIS, EVANGELOS BALTAS \\ Department of Water Resources and Environmental Engineering \\ School of Civil Engineering, National Technical University of Athens \\ Iroon Politechniou 5, 15780 Zografou \\ GREECE
}

\begin{abstract}
The prolonged issues regarding the quantita tive and qualitative characteristics of the water resources in the River Basin District of Thessaly (TRBD) have resulted in the environm ental degradation and the reduction of the availability of water. Agriculture is the major water user, constituting up to $95 \%$ of total water demand. The pressures anticipated from the ongoing climate change are expected to cause further degradation, given the present status of the water resources. This research attempts to examine and quantify the water saving potential of TRBD, mainly for the agriculture sector, following the recommendations of the European legislation, the principles of sustainab le development and environmental protection. Water saving $t$ ools are documented in several countries, incl uding technical measures, such as dr ip irrigation sy stems and the modernization of the transfer networks, as well as deficit and scheduled irrigation practices and water reuse. These measures and practices are tested for their poten tial effect on water dem and in TR BD, in addition to changing a portion of cott on cultivation areas to olive grov es. To this end, the volume of i rrigation demand is estimated at $2088 \times 10^{6} \mathrm{~m}^{3}$, while total water demand stands for $2204 \times 10^{6} \mathrm{~m}^{3}$. Afterwards the study proceeds to the evaluation of the water saving potential both independently and combined. The potential of water savings in TRBD is proven high, $14.3 \%$ of total water demand for technical measures, $10.7 \%$ if deficit irrigation is applied to specific crops, while it may reach $28.8 \%$ in case the measures are combined.
\end{abstract}

Keywords: WFD, RBD of Thessaly, Water saving, Irrigation, Water resources management.

Received: November 27, 2019. Revised: March 10, 2020. Accepted: April 20, 2020. Published: April 26, 2020.

\section{Introduction}

TRBD is in Central Greece and is co nsidered the major agricultural region of Gre ece. Numerous water bodies, both surface and undergr ound, have been recorded by the RBDMPs facing quantitative and quality degradation [1]. The above are thought to be caused due to poor managem ent and overexploitation of water resources [2]. Moreover, the droughts of previous decades have revealed the significant water scarcity TRBD is facing [3]. TRBD is water stressed, with an annual average of Water Exploitation Index plus estimated about $30.8 \%$ [4].

Considering the expected implications of climate change in southern Europe, water s carcity as well as the occurrence and intensity of droughts, is expected to be intensified, resulting in $\mathrm{m}$ ore pressures to the water resources. As far as the agricultural sector, it is expected that climat e change will cause an increase to crops' irrigation water re quirements. This is attrib uted to shortage of rainfall as also to increase of temperature, resulting in the increase of evapotranspiration Water efficient technologies are considered a significant to ol towards the adaptation to climate change [5].

Following the notion of both th $\mathrm{e}$ Water Framework Directive 2000/60/EC (WFD) and of the
Brundtland report, the River Basin District (RBD) is considered the most suiting unit towards achieving sustainable development and water resources management [6]. The identification of , both point and diffused pressures is followed by the evaluation of their impacts on water resources of the RBD. The impact evaluation is followed by the formation a River Basin District Managem ent Plan (RBDMP), which includes a specific Programme of Measures (PoMs), towards achieving hi gh quality (chemical/ecological) and quantitative status for the water bodies. Sustainability is therefore a term , as also a target for water resources management.

Achieving high levels of water use efficiency is considered essential [7]. Besides reducing pressures to water resources, high efficiencies have beneficial effects for the adopting users. This can be achieved through water saving mea sures and practices, reducing water demand and proper co st recovery strategies. Since, the agricultural sector is the major water user in TRBD, [2], emphasis is given at this study to water savings in irrigation. A change of water transferring and application technolo gies, as well as the adoption of water saving practices, has displayed in many cases significant beneficial effects on agricultural water consumption.

The modernization of water networks, primaril y with the lining and autom atization of open channels 
rationalizes water transfers [8]. The construction of pressurised pipes provides the most efficient way of transferring water [9]. In the RBD of Ebro, Spain, two national modernization projects, including the shift to pressurised pipes as well as the adoption of drip irrigation, aim at reducing irrig ation water demand about $15 \%$, while increasing the productivity of both water and land [10]. In TRBD, even urban pressurized networks display high losses, at 29.9\% [11 ]. This implies the necessity of proper maintenance of existing piped networks [12].

The application of the irrigation water is generally done by three methods: surface/gravity, (b) sprinkler and (c) drip with efficiencies of $60 \%, 75 \%$ and $90 \%$ respectively [13]. The modernization of the application methods, in combination with press urised pipes, can reduce irrigation demand up to $50 \%$ [9].

The use of drip irrigation sy stems has been documented to result in water savings up t o $60 \%$, reduction of fertilizers usage, and so of quantitative and quality pressures to water bodies [ 14]. Additionally, increase of water productivit $y$ is documented, along with raise of the value of produced crops with reduced water consumption [15]. Moreover, the reduction of crops infections is attributed to the usage of drip irrigation $\mathrm{s}$ ystems [16].

Site specific case study has reported that drip irrigation of sugar beets in Sout h Italy gives higher production compared to sprinkler irrigation. Specifically, for drip irrig ation at $50 \%$ of the crops irrigation needs, sucrose production is $10.6 \mathrm{t} / \mathrm{ha}$, while sprinkler irrigation at $100 \%$ of the crops irrigation needs results in $9.3 \mathrm{t} / \mathrm{ha}$ of sucrose production [17]. In Anatolia, Turkey, irrigation of cotton with drip s ystems gives $t$ he highest production and water productivit $\mathrm{y}$, regarding the three methods of irrigatio $n$ [18]. In Brazil, tomato cultivation using drip irri gation systems gave also higher water productiv ity compared to sprinkler, while reducing water demand by $31 \%$ [19].

Setbacks of adopting drip irrigation are also examined. In areas of low precipitation , about 200 $\mathrm{mm} /$ year, there has been observed increase of soil salinity [16]. In Spain, an increase of energy consumption, irrigated areas and crops have also been recorded [20]. The above are not considered significant enough regarding TRBD to outweigh the water saving potential of shifting to drip irrigation. Two more aspects of the adoption of the aforementioned new technologies are clarified by Berbel et al. [14]. These are the legal fra mework regarding water usage, which shoul $d$ include an upper limit to water abstractions and the need of an intensive attempt to provide farm ers the proper advice.

Scheduled irrigation is considered the calculation of the optimum water quantity, duration and time of irrigating a crop [ 13]. In Zaragoza, Spain, proper irrigation scheduling ha $\mathrm{s}$ increased water us $\mathrm{e}$ efficiency by $16 \%$, saving $17 \mathrm{~m}^{3} / 10^{3} \mathrm{~m}^{2}$ without altering crop yields [21]. Additionally, developments of software and low-co st moisture sensors are considered an extra tool for proper irrigation scheduling. In California, it is estim ated that water demand can be reduced by $10 \%$ only via irrigation scheduling [15]. Many crops, even with high sensitivity to water shortage, can withstand deficit irrigation, if the latter is done properly, employing irrigation scheduling [22].

Deficit irrigation is considered as the exposure of crops to specific level $\mathrm{s}$ of water stress for their growth season, or a specific growing period, without causing a significant reduction of their yields [23]. In California, it is esti mated that deficit irrigation under proper scheduling, may reduce water deman d by $3.14 \%$, while increasing the quality of the products [15]. Also, con sidering the competitive uses of freshwater, an increase of a farmer's income may be attributed to deficit irrigation [24]. It should be noted that major crops in TRBD, such as cotton and olive trees are cons idered resistant to water stress [13].

Water reuse is considered to reduce outflows to possibly sensitive receiving water bodi es [25]. It is also accredited of saving freshwater usage and fertilizers, as far as agriculture is concerned $[25,26]$. Water reuse may also be applied i $\mathrm{n}$ recharging aquifers with quantitative or salt-water intrusion problems [27]. Numerous potential uses ar e referenced, such as urban, industrial, recreational etc. Regarding agricultural water reuse for irrigation purposes, many countries are reusing treated wastewater. Spain, Italy, Cyprus and Israel are some examples where treated wastewater is used for irrigation purposes under financial sustainabilit $y$ while saving abstractions of freshwater.

Water reuse in agriculture may increase the quantity and/or the quality of products [28] along with reducing the use of fertil izers [29]. Furthermore, it raises the fertility of poor-quality soils [30]. A concern regarding water reuse may be considered the increase of soil salinity in $m$ any cases. Recent studies have also focused on the presence and potential danger to human health of Emerging Organic Co ntaminants (EOCs) and Antibiotic Resistant Genes (ARGs) [31, 32]. Drip irrigation and irrigating non eaten raw crops are some of the key solutions of the above research. 


\section{Study area - Data used}

\subsection{Study area}

TRBD, shown in Fig. 1 (Appendix), is alm ost identical to the prefecture of Thessaly, covering an area of about $13000 \mathrm{~km}^{2}$. It is co mprised of two sub-basins, the Pinios river basin $\left(11000 \mathrm{~km}^{2}\right)$ and the river basin of Almiros-Pilion $\left(2000 \mathrm{~km}^{2}\right)$ [1]

The climate conditions are mainly grouped in three categories; the eastern part has a

Mediterranean climate, the central plain a continental and the western a $\mathrm{m}$ ountainous with high rain and snow accum ulations. The average annual rainfall and temperature of TRBD are estimated at $678 \mathrm{~mm}$ and 16-17 $\cong \mathrm{C}$, respectively [1].

The central plain, the largest plain of Greece, is crossed by the Pinios river, which flows fro $m$ west to east. Othe $r$ major tributaries, such as Enipeas, Sofaditis and Titarisios contribute to Pi nios, whose total length counts $213 \mathrm{~km}$ while its annual runoff is estimated about $3165 \times 10^{6} \mathrm{~m}^{3}$. The central plain also hosts aq uifers of significant capa city, created from Quaternary deposits and Neogen e sediments [1].

Human activity is con centrated around fi ve major cities, Larisa, Volos, Karditsa, Trikala and Tirnavos. Agricultural land use accounts for $45 \%$ of total land in the sub-basin of Pinios and $34 \%$ in the Almiros - Pilion sub-basin [1].

The implementation of the WFD resulted in the recording of 82 surface water bodies, of which 72 are river, 3 heavily modified ( 2 lakes and 1 riverlake) and 7 coastal water bodies [1]. 47/72 (65\%) of the river water bodies are subjected to high seasonal (summer) quantitative pressure, having abstractions over the $50 \%$ of the average summer runoff. Annual quantitative pressure is found high in 8/72 (11\%), while another 8 river wat er bodies face moderate pressures. Out of the 72 river water bodies, none has high and only 30/72 (42\%) have good ecological status. Chemical status is found goo $d$ in 56/72 (78\%) river water bodies. Abstractions from surface water bodies are mentioned in the RBDMP as $300 \times 10^{6} \mathrm{~m}^{3}$.

TRBD hosts water storage infrastructure of about $320 \times 10^{6} \mathrm{~m}^{3}$ [33]. Additionally, the recreation of Lake Karla is expected to store $60 \times 10^{6} \mathrm{~m}^{3}$ of water to be abstracted.

Groundwater is considered the $\mathrm{m}$ ain source of freshwater in TRBD. A bstractions are estimated about $923 \times 10^{6} \mathrm{~m}^{3}$, where renewable reso urces are $1891 \times 10^{6} \mathrm{~m}^{3}$ for the groundwater bodies. Out of the 33 recorded bodies of gr oundwater, $10(30 \%)$ are reported as in poor quantitative status. Moreover, due to lon g-term overexploitation, a $r$ eduction of non-renewable water quan tities is observed around $3000 \times 10^{6} \mathrm{~m}^{3}$ [1]. Water level is recorded is so me cases to have fallen from 15 up to $100 \mathrm{~m}$ below the levels of pa st decades [34]. Furthermore, many incidents of subsidence are attributed to overabstractions of aquifers [ 35]. Regarding their chemical status, $4(12 \%)$ groundwater bodies are reported as in poor state.

The main driver of qua ntitative and qualit $y$ pressures is the agricultural sector [1]. Numerous unregistered private wells contribute to the degradation of water $r$ esources, while loc al authorities do not promote the efficient use of water resources [36].

TRBD hosts 15 Wastew ater Treatment Plants (WWTPs). Among them, Larisa, Volos, Trikala and Karditsa have an annual average inflow of $35.35 \times 10^{6} \mathrm{~m}^{3}$, the bigges $\mathrm{t}$ share of the total $40.38 \times 10^{6} \mathrm{~m}^{3}$. All of them have secondar $y$ treatment, while the vast majority does also tertiary treatment [37]. In TRBD, a survey has give $n$ positive feedback regarding far mers' willingness to pay for treated wastewater [38], while in the nearby basin of Nestos, $64.2 \%$ of farm ers were found willing to pay for treated wastewater at a price lower than freshwater [39].

\subsection{Data used}

The available data about crop cultivation areas and production have been obtained from the production records in the prefecture of Thessaly [40]. Taking under consideration the insignificant spatial difference between the pr efecture and TRBD, as also the fact that the main agriculture activity occurs in the central plain, part of both, using t his data will cause no sig nificant variations over the cal culation of irrigation demand.

Wheat and other cereals (except maize) are found to be the most widely cultivated crops in an area of $1525 \mathrm{~km}^{2}$. Cotton follows with a cultivated area of $842 \mathrm{~km}^{2}$, while olive groves cover an area of $286 \mathrm{~km}^{2}$. Trees, other than olive groves are al so cultivated in an area of $233 \mathrm{~km}^{2}$. Significant cultivation of clovers $\left(298 \mathrm{~km}^{2}\right)$ and maize (261 $\mathrm{km}^{2}$ ) is also observed. The sum of cultivated areas equals $3906 \mathrm{~km}^{2}$ [40]. The distribution of the above crops' cultivation areas is displayed in Figure 2. 


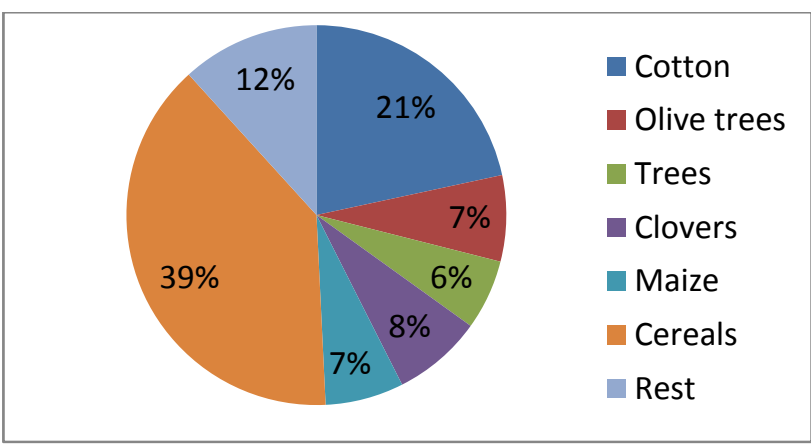

Figure 2, Major crops cultivation areas in TRBD

Irrigation water requirements data have been calculated by Vagenas [ 41] for the regions of Magnesia and Larisa, pa rts of TRB D. For so me widely cultivated crops like cotton, sugar beets, wheat and maiz e, irrigation needs are calculated specifically, while for others, the irrigation needs are calculated by category of crops (ex. Tree s, horticulture, etc.). In Table 1 exa mples of the above data are dis played. Olive trees in Greece are suggested to be irrigated with $290 \mathrm{~mm}$ [ 42], instead of $496 \mathrm{~mm}$ mentioned by Vagenas [41] for trees.

Table 1, Indicative crops cultivated area and irrigation needs

\begin{tabular}{ccc}
\hline Crop & $\begin{array}{c}\text { Cultivated } \\
\text { area }\left(\mathbf{k m}^{\mathbf{2}}\right)\end{array}$ & $\begin{array}{c}\text { Irrigation } \\
\text { needs }(\mathbf{m m})\end{array}$ \\
\hline Cotton & 841.73 & 499.1 \\
Sugar beets & 10.86 & 636.7 \\
Maize & 260.87 & 529.9 \\
Clover & 298.01 & 612.9 \\
Vines & 51.61 & 301.4 \\
Horticulture & 78.51 & 457.2 \\
\hline
\end{tabular}

The only data source reg arding the freshwater abstractions was the 1 st Revision RBDMP of Thessaly [1]. Concerning the surface water bodies, information was available for their a nnual runoff, abstracted water volume and the intensity of abstraction. In Table 2, e xamples of surface water bodies consisting river sections, along with their annual abstractions of water, are display ed. For the groundwater bodies the volumes of naturally fed and abstracted water were documented.

Table 2, Examples of surface water bodies and their annual freshwater abstractions, [1]

\begin{tabular}{cc}
\hline Surface water body & $\begin{array}{c}\text { Annual water } \\
\text { abstractions }\left(\times \mathbf{1 0}^{\mathbf{6}} \mathbf{m}^{\mathbf{3}}\right)\end{array}$ \\
\hline Pinios R.1 & 687.73 \\
Pinios R.8 & 468.18 \\
Enipeas R.1 & 421.98 \\
Enipeas R.2 & 55.59 \\
Sofaditis R.1 & 201.06 \\
Sofaditis R.2 & 93.46 \\
\hline
\end{tabular}

In TRBD ab out $78.3 \%$ of cultivation areas have their irrigation water ob tained by private wells, while the rest are supplied via public networks [43]. Michas and Gkiokas [43] have documented current distribution of water transferring methods for public irrigation schemes in three out of four prefectures of TRBD, as shown in Table 3. It is notable that only in prefecture of Trikala irrigation water transferring is performed mainly with pressurise d networks. Nevertheless, efficiency of pressuris ed networks is found about $75-80 \%$, lower than the optimal operative value of $90 \%$ [9]. Moreover, efficiency of open channels is ranging from 52 to $60 \%$.

Table 3, Public networks water transferring technologies [43]

\begin{tabular}{cccc}
\hline $\begin{array}{c}\text { Prefecture } / \\
\text { Type }\end{array}$ & Larisa & Trikala & Karditsa \\
\hline $\begin{array}{c}\text { Pressurised, } \\
\text { underground } \\
\text { pipes }\end{array}$ & $11 \%$ & $15 \%$ & $5 \%$ \\
$\begin{array}{c}\text { Pressurised, } \\
\text { surface pipes }\end{array}$ & $30 \%$ & $82 \%$ & $31 \%$ \\
$\begin{array}{c}\text { Open channels, } \\
\text { lined }\end{array}$ & $5 \%$ & - & $35 \%$ \\
$\begin{array}{c}\text { Open channels, } \\
\text { not lined }\end{array}$ & $54 \%$ & $3 \%$ & $32 \%$ \\
\hline
\end{tabular}

For the field application technologies regarding the public networks, there is data for the 53 irrigation management authorities of TRBD [44]. The volumes of irrigation requirements and on-field irrigation demand, which includes the application losses, are available. Application losses are considered in the Supporting document \#8 [44], as $80.75 \%$ for sprinkler irrig ation systems and as $85 \%$ for drip irrigation s ystems. Application losses for the areas irrigated from the authorities range fro $\mathrm{m}$ $16.63 \%$ to $21.39 \%$, averaging $19.09 \%$ of irrigation needs. No data is avai lable as far as private irrigation is concerned.

Regarding water uses except agricultural, water demand data is obtained from the $1^{\text {st }}$ Revision of the RBDMP of Thessaly [1]. Urban water demand stands for $94 \times 10^{6} \mathrm{~m}^{3}$, industrial water demand for $9 \times 10^{6} \mathrm{~m}^{3}$ and water demand for live stock for $13 \times 10^{6} \mathrm{~m}^{3}$.

\section{Methodology}

\subsection{Water demand}

The current status of water dem and is mapped, especially for the agriculture sector. Data about crop cultivation areas and irrigation needs are co mbined 
with the doc umented technologies that are used to transfer and apply the irrigation water, in order to estimate the current irrigation dem and for TRBD. Irrigation demand is calculated when water transfer and application losses are included in irrigation needs. This is done separately for irrigated land by public networks (publicl y irrigated) and private wells (privately irrigated), as described in equations (1), (2).

$$
\begin{gathered}
I D=I D_{P r}+I D_{P N} \\
I D_{i}=\frac{I N_{i}}{\left(A E_{i} \times T E_{i}\right)}
\end{gathered}
$$

Where:

$I D$ : Total irrigation water demand of TRBD

$I D_{i}$ : Irrigation demand

$I N_{i}:=\alpha_{i} \times I N$, Irrigation needs,

$\alpha$ : the percentage of area

$A E_{i}$ : Application efficiency

$T E_{i}$ : Transfer efficiency

Where $\operatorname{Pr}$ stands for privately irrigated areas

and $P N$ stands for publicly irrigated areas

For the calculation of tota 1 irrigation needs, $I N$, the sum of each crop's water requirements is calculated. Due to the gap s of knowled ge for some crops' irrigation needs and the expected

implications of climate ch ange, the calculated value is amplified by $10 \%$. The amplified value stands for TRBD's total irrigation needs. This is display ed in equation (3).

$$
I N=1.1 \times \sum_{j=1}^{n}\left(C A_{j} \times I n_{j}\right)
$$

Where:

$I N$ : Total irrigation needs of TRBD

$C A_{j}$ : Cultivated areas

$I n_{i}$ : Irrigation needs

For the publicly irrigated areas, tra nsfer and application efficiencies are calculated. Taking under account: (a) open, not lined channels have an efficiency of $60 \%$, open, lined channels $70 \%$ and pressurised pipes $90 \%$, when properly operated [9] and (b) the size of ea ch prefecture, an averaged $T E_{P N}$ is cal culated. This averaged efficie ncy is considered mutual also for the prefecture o $\mathrm{f}$ Magnesia. Application efficiency derives fro $m$ the average ratio of application losses documented fro $m$ the irrigation management authorities and the considered efficiencies. Calculating the present distribution of ap plication technologies an $d$ applying their efficiencies, as mentioned by Dworak [9]; for drip and sprinkler irrigation s ystems, 90\% and $75 \%$ respectively, results in the value of $A E_{P N}$.

As far as privately irrigated areas are concerned, it is assu med: (a) there are no tra nsfer losses
$\left(T E_{P r}=1\right)$ and (b) there is a slight more efficient usage of application methods than public networks.

Total water demand is the sum of total irrigation water demand, urban water demand, industrial water demand and livestock water demand.

\subsection{Freshwater abstractions}

The lack of recording gross water abstractions from surface water bodies drives the research to an estimation of the afore mentioned quantity. This is done taking into account: (a) the recorded abstractions from each water bo dy, (b) that abstractions are calculated as "Gross abstractions Returns" for each water body, (c) the majority of rivers are divided in sections, each se ction constituting a river water body and (d) that abstractions from upstream water bodies are included in every downstream water body [44].

\subsection{Water saving potential}

Since the beneficial effect of the discussed technologies and practices towards water saving is recognized, the methods are applied to TRBD. Their effect in reducing water dem and is calculated for various scenarios and their combination. Lastly, as a measure with both financial sustainability and water saving potential, changing the $m$ ixture of two widely cultivated crops (cotton and olive trees) i $\quad$ S also tested for its water saving capacity.

Technical measures include the modernization of public irrigation water netw orks (M), offering $90 \%$ efficiency [12], along with the adopt ion of dri $\mathrm{p}$ irrigation methods instead of sprinkler, at X \% of cultivated areas (D at $\mathrm{X} \%$ ). Drip irrigati on systems when properly operated are thought $t \mathrm{o}$ apply the irrigation water with $90 \%$ efficiency. Their effect on total water demand is calculated by altering $T E_{i}$ and $A E_{i}$ for the m odernization of networks and the adoption of drip irrigation systems respectively.

The examination of scheduled irrigation is done in combination with defic it irrigation (SDI). Crops examined are cotton $(\mathrm{C})$, olive trees $(\mathrm{O})$ and the rest of the trees $(\mathrm{T})$ cultivated in TRBD. SDI at $\mathrm{X} \%$ stands for scheduled deficit irrigation at $\mathrm{X} \%$ of crop irrigation needs. Olive trees, since thei $\mathrm{r}$ significant ability to withstand water stress, are exam ined in some cases separate from the rest of the trees, for irrigation needs at $290 \mathrm{~mm}$. For the cases examined, the calculation of water savings is done by changing the $I n_{j}$, for the crops examined.

Hence, achieving sustainable $f$ reshwater abstractions is the long-te $\mathrm{rm}$ target, further water 
saving measures may be required. Water reuse provides an alternative, easily accessible water source, at lea st from the four major WWTPs. The quantity of water reuse reduces total demand for freshwater abstractions. Additionally, regarding that ginned cotton productivity is low, about $0.50 € / \mathrm{m}^{2}$ $[40,45]$ and its irrigati on needs are high, this research engages the $\mathrm{w}$ ater saving potential of changing cotton cultivation areas with olive groves. Olive trees, producing olive oil, in Gr eece present average productivity of $0.37 € / \mathrm{m}^{2}$, while requiring less cultivation cost $[40,46]$. The change is examined for different spatial extents, under SDI of olive trees a t $290 \mathrm{~mm}$. The calculation of water savings of $\mathrm{t}$ he above $\mathrm{m}$ easure is performed by altering $C A_{j}$ for cotton and olive grove s, while In $n_{\text {olives }}=290 \mathrm{~mm}$.

\section{Results - Discussion}

\subsection{Water demand}

Following the methodology towards the calculation of total water demand, $T E_{P N}$ is c alculated at $75.99 \%$. Regarding ap plication efficiency, drip irrigation systems are found to be used in the $9 \%$ of publicly irrigated areas, while the rest $91 \%$ is irrigated with sprinkler sy stems, resulting in be $A E_{P N}$ of $76.14 \%$. Therefore, for the privately irrigated areas, it is assu med that $30 \%$ of irrigation is performed by drip irrigation systems and the rest $70 \%$ by sprinkler systems. The above assu mption, results in the esti mation of $A E_{P r}$ at $78.95 \%$. These results, displayed in Table 4, demonstrate the significant impacts of transferring irrigation water with a non-efficient network to overall efficiency . While $A E$ is similar for both irrigat ion regimes, overall efficiency for public networks is lower by more than $20 \%$.

Table 4, Efficiency parameters

\begin{tabular}{ccc}
\hline & Public networks & Privately irrigated \\
\hline $\boldsymbol{A} \boldsymbol{E}_{\boldsymbol{i}}$ & $76.14 \%$ & $78.95 \%$ \\
$\boldsymbol{T} \boldsymbol{E}_{\boldsymbol{i}}$ & $75.99 \%$ & $100 \%$ \\
$\boldsymbol{A} \boldsymbol{E}_{\boldsymbol{i}} \times \boldsymbol{T} \boldsymbol{E}_{\boldsymbol{i}}$ & $57.86 \%$ & $78.95 \%$ \\
\hline
\end{tabular}

As mentioned, $78.3 \%$ of cultivation areas are privately irrigated and the rest $21.7 \%$, publicly irrigated. Therefore, $\alpha_{P N}$ equals to 0.783 and $\alpha_{P r}$ to 0.217 . The results regarding ke y volumes towards the calculation of present total irrigation water demand are displayed in Table 5.
Table 5, Key volumes of present status

\begin{tabular}{cc}
\hline Present volumes & $\mathbf{1 0}^{\mathbf{6}} \boldsymbol{m}^{\mathbf{3}}$ \\
\hline $\boldsymbol{I N}$ & 1527.28 \\
$\boldsymbol{I N}_{\boldsymbol{P N}}$ & 332.03 \\
$\boldsymbol{I}_{\boldsymbol{P r}}$ & 1195.25 \\
$\boldsymbol{I D}_{\boldsymbol{P N}}$ & 573.86 \\
$\boldsymbol{I}_{\boldsymbol{P r}}$ & 1513.98 \\
$\boldsymbol{I D}$ & 2087.84 \\
\hline
\end{tabular}

The concluded value of total irrigation needs $(I N)$ for TRBD is $1527 \times 10^{6} \mathrm{~m}^{3}$. Total irrigat ion water losses are calculated, as the differenc e between demand and needs, at $561 \times 10^{6} \mathrm{~m}^{3}$. Privately irrigated areas present $319 \times 10^{6} \mathrm{~m}^{3}$ losses, the $26.7 \%$ of their irrigation needs $\left(1195 \times 10^{6} \mathrm{~m}^{3}\right)$. On the other hand, losses are found to be $242 \times 10^{6}$ $\mathrm{m}^{3}$ for the areas irrigated with public networks, the $72.9 \%$ of their irrigation needs $\left(332 \times 10^{6} \mathrm{~m}^{3}\right)$. Total present irrigation dem and (ID) is calcul ated at $2088 \times 10^{6} \mathrm{~m}^{3}$.

Total water demand accounts for $2204 \times 10^{6} \mathrm{~m}^{3}$. Irrigation water losses, $25.44 \%$ of total water demand, constitute a large share in the formation of irrigation demand, espe cially for areas irrigated from public networks. Ad ditionally, it is observed that irrigation demand stands for $94.74 \%$ of total water demand, confirming that emphasis should be given in water saving in the agriculture sector.

\subsection{Freshwater abstractions}

Freshwater abstracted from groundwater bodies is estimated by the $1{ }^{\text {st }}$ Revision of the RBDMP of Thessaly at $923 \times 10^{6} \mathrm{~m}^{3}$.

For the surface fr eshwater abstractions, the following can be extract ed from the $1{ }^{\text {st }}$ Revision of the RBDMP of Thessaly [1]. Firstly, the m ost downstream sections of tributaries of Pinios have water abstractions calculated at $754 \times 10^{6} \mathrm{~m}^{3}$. Pinios river sections 8 to 5 have abstractions of $117 \times 10^{6}$ $\mathrm{m}^{3}$. River water bodies, discrete fro $\mathrm{m}$ Pinios, have abstractions of $9.0 \times 10^{6} \mathrm{~m}^{3}$. The abstractions of Pinios sections 12 to 9 and 4 to 1 are not calculated, as well as of the upstream sections of its tributaries. All the above quantities are not referring $t$ o gross abstractions, but "Abstractions - Returns". "Abstractions - Returns" are calcula ted by the present research to be at least $880 \times 10^{6} \mathrm{~m}^{3}$, based on the RBDMP data.

Considering the above, it is assu med, that gross water abstractions from surface water bodies are $1000 \times 10^{6} \mathrm{~m}^{3}$. Then total water abstractions can be considered about $1923 \times 10^{6} \mathrm{~m}^{3}$. 
Difference from total water demand then is about $15 \%$, a reasonable percentage due to the unknown exact quantity of abstract ed surface freshwater and the numerous unregistered private wells. It is evident that gross abstrac tions from surface water bodies vary from the abstractions mentioned in the $1^{\text {st }}$ Revision of the RBDMP of Thessaly [1 ]. This can be attributed to the method of presenting the abstracted volumes in the RBDMPs, concealing the exact volumes of gross abstractions and water returns and as an effect, lacking the nece ssary clarity.

\subsection{Water saving potential}

The highest volume of saved water occurring for the adoption of the technical measure $\mathrm{s}$ mentioned is $315 \times 10^{6} \mathrm{~m}^{3}, 14.3 \%$ of total water demand, as shown in Fig. 3. This amount of saved water occurs with the widespread adoption in $90 \%$ of cultivation area $\left(3515 \mathrm{~km}^{2}\right)$ of drip / micro-sprinkler irrigation systems combined with the full modernization of public irrigation water networks.

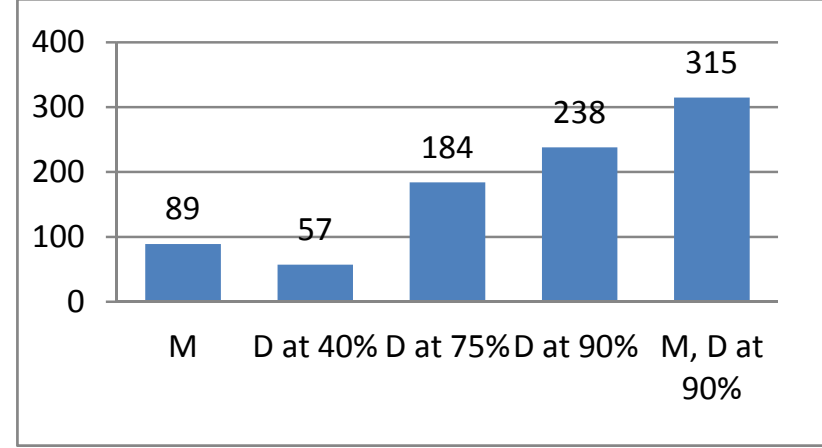

Figure 3, Technical measures water savings, $\left(\times 10^{6} \mathrm{~m}^{3}\right)$

The above combination compared to the present status, alters $A E_{P N}$ from $76.14 \%$ to $88.24 \%, A E_{P r}$ from $78.95 \%$ to $88.24 \%$ and $T E_{P N}$ from $75.99 \%$ to $90.00 \%$. As a result, irrigation water demand (ID) is reduced by the aforementioned quantity.

The most effective application of scheduled deficit irrigation, as display ed in Table 6 , is that of SDI at $80 \%$ for cotton and trees, while olive trees are irrigated with $290 \mathrm{~mm}$, saving $235 \times 10^{6} \mathrm{~m}^{3}$, $10.67 \%$ of total water demand. These savings are achieved by reducing the irrigation $\mathrm{n}$ eeds (In) of cotton, trees and olive trees, resulting in a decrease of $I N$, and therefore of $I D$.
Table 6, Scheduled deficit irrigation water saving

\begin{tabular}{cc}
\hline Measure & $\begin{array}{c}\text { Water savings } \\
\left(\times \mathbf{1 0}^{\mathbf{6}} \mathbf{m}^{\mathbf{3}}\right)\end{array}$ \\
\hline C SDI at $90 \%$ & 58 \\
O SDI at $90 \%$ & 20 \\
C, O SDI at $90 \%$ & 77 \\
C, O SDI at $80 \%$ & 154 \\
C, O \& T SDI at $80 \%$ & 193 \\
C \& T SDI at $80 \%$, & 235 \\
O SDI at $290 \mathrm{~mm}$ & \\
\hline
\end{tabular}

Combination of technical measures and scheduled deficit irrigation $m$ ay result in significant volumes of saved water, while having a minimum negative impact in crop prod uction. Even moderately effective measures, in case of combining, may save larger volum es of water. This is attributed to the reduction of In of the sele cted crops, simultaneously to the improvement of the efficiency factors.

As shown in Table 7, the modernization of networks when combined with the widespread use of drip s ystems and scheduled deficit irrigation of cotton, olive groves and trees in TRBD is capable of water savings about $479 \times 10^{6} \mathrm{~m}^{3}, 21.74 \%$ of tota 1 water demand.

Table 7, Combinations of technical measures and scheduled deficit irrigation

\begin{tabular}{cc}
\hline Measure & $\begin{array}{c}\text { Water savings } \\
\left(\times \mathbf{1 0}^{\mathbf{6}} \mathbf{m}^{\mathbf{3}}\right)\end{array}$ \\
\hline $\begin{array}{c}\text { D at } 40 \%, \mathrm{C}, \mathrm{O}, \mathrm{SDI} \text { at } \\
90 \%\end{array}$ & 132 \\
$\begin{array}{c}\text { D at } 75 \%, \mathrm{C}, \mathrm{O}, \mathrm{SDI} \text { at } \\
90 \%\end{array}$ & 254 \\
$\begin{array}{c}\mathrm{M}, \mathrm{D} \text { at } 90 \%, \mathrm{C}, \mathrm{O}, \mathrm{T} \\
\text { SDI at } 80 \%\end{array}$ & 479 \\
\hline
\end{tabular}

Water reusing from the four major WWTPs may save $35 \times 10^{6} \mathrm{~m}^{3}$ in total. Scenarios are examined for different extents of change from cotton cultivation to olive gr oves. A change of $15 \%$ of cotton cultivated areas $\left(127 \mathrm{~km}^{2}\right)$ to olive groves, may reduce water demand by $117 \times 10^{6} \mathrm{~m}^{3}$. A wider swift from cotton plants to olive trees in the $60 \%$ of the cotton cultivated area $\left(507 \mathrm{~km}^{2}\right)$ can decrease water demand by $225 \times 10^{6} \mathrm{~m}^{3}, 10.21 \%$ of total water demand, as $I N$ is reduced by $165 \times 10^{6} \mathrm{~m}^{3}$.

Finally, the co mbination of all mentioned measures results in wa ter savings of $634 \times 10^{6} \mathrm{~m}^{3}$, $28.75 \%$ of total wat er demand. This p otential may be achieved after networks are modernized and properly operated, drip irrigation is used widely , at $90 \%$ of cultivated areas, cotton cultivated areas 
become olive groves at $60 \%$, olive trees are irrigated with $290 \mathrm{~mm}$, while the rest of the trees and the remaining cotton receive scheduled deficit irrigation at $80 \%$ of their needs and wastewater is reused from the four major cities. Figure 4 breakdowns current and the disc ussed highest water saving scenario's water demand. It should be noted that for the water saving scenario abstracted water is lower than total water demand by the volume of reused water, $35 \times 10^{6} \mathrm{~m}^{3}$.

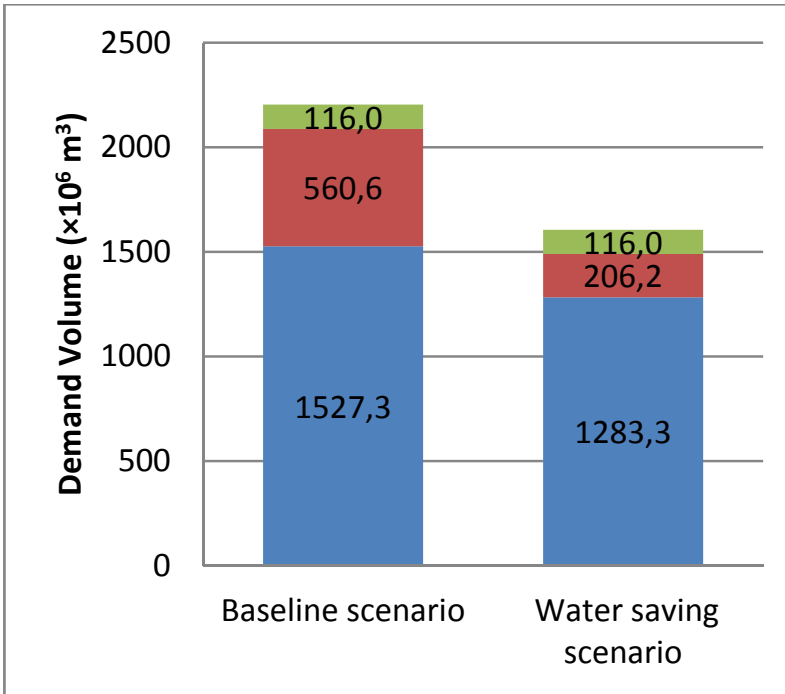

Irrigation needs $\square$ Irrigation losses $\square$ Other uses

Figure 4, Total water demand breakdown for baseline and highest water saving scenarios

Table 8 presents the differences regarding $\mathrm{k}$ ey parameters for the present and the most water saving scenario. Transfer and application efficiencies a re highly increased. Irrigation demand still constitutes $92.77 \%$ of total water demand. Nevertheless, $I N$ and irrigation water losses are reduced by $244 \times 10^{6} \mathrm{~m}^{3}$ and $355 \times 10^{6} \mathrm{~m}^{3}$ respectively. $I D_{P r}$ is reduced b y $376 \times 10^{6} \mathrm{~m}^{3}, 25 \%$ of its present value. On the other hand, $I D_{P N}$ is reduced by $223 \times 10^{6} \mathrm{~m}^{3}, 39 \%$ of its present value. Reused water can be applied either in aquifer recharging or for urban green spaces uses. The amount of potentially saved water equals about $42 \%$ of present $I N$.

Table 8, Impact of combined measures on key parameters

\begin{tabular}{cc}
\hline Parameter & Difference \\
\hline $\boldsymbol{A} \boldsymbol{E}_{\boldsymbol{P N}}(\%)$ & +12.10 \\
$\boldsymbol{A} \boldsymbol{E}_{\boldsymbol{P r}}(\%)$ & +9.29 \\
$\boldsymbol{T} \boldsymbol{E}_{\boldsymbol{P N}}(\%)$ & +14.01 \\
$\boldsymbol{I N}\left(\times \mathbf{1 0}^{\mathbf{6}} \mathbf{m}^{\mathbf{3}}\right)$ & -243.98 \\
\hline
\end{tabular}

\section{Conclusions - Future research}

The aim of the present research work is the calculation of the water saving potential of TRBD. In order to achieve it, the irrigation water dem and is calculated to be $2088 \times 10^{6} \mathrm{~m}^{3}$, constituted of irrigation needs, up to $1527 \times 10^{6} \mathrm{~m}^{3}$, in addition to transfer and application 1 osses, up to $561 \times 10^{6} \mathrm{~m}^{3}$. The total water demand, including $\mathrm{t}$ he domestic, industrial and livestock sectors, is $2204 \times 10^{6} \mathrm{~m}^{3}$.

Moreover, the pres ent research concludes that gross abstractions from surface water bodies are at least $880 \times 10^{6} \mathrm{~m}^{3}$. Irrigation water distribution networks present low efficiency, less than 58\%. Irrigation via private wells consist a $\mathrm{m}$ ajor driver of quantitative pressures for the groundwater bodies, as its demand stands for the $80 \%$ of their annual renewable resources. Additionally, the fact that $65 \%$ of river water bodies are subjected to hig $h$ quantitative pressures, $\mathrm{i}$ mplores the need of a sustainable solution. Under this co ntext, water saving measures have been examined, as a solution, less disturbing to the environm ent, compared to the construction of new storage infrastructure.

Water savings potential is calculated up to $315 \times 10^{6} \mathrm{~m}^{3}$, or $14.3 \%$ of to tal water demand fo $\mathrm{r}$ technical measures, comprised of s wift to drip irrigation systems and the modernization of water distribution networks. Deficit irrigation under proper scheduling for cotton, olive groves and trees cultivation may also save $235 \times 10^{6} \mathrm{~m}^{3}, 10.7 \%$ of total water demand. Changing $507 \mathrm{~km}^{2}(60 \%$ based on current crop area) of cotton cultivation areas to olive groves, results in savings of $225 \times 10^{6} \mathrm{~m}^{3}$, $10.2 \%$ of total water de mand, if olive trees are irrigated with $290 \mathrm{~mm}$. Combining the aforementioned measures in TRBD, along with water reuse, water savings may reach a volum e of $634 \times 10^{6} \mathrm{~m}^{3}, 28.8 \%$ of the total water demand.

These results demonstrate the large water saving potential of TRBD, which is judged capable of providing a significant relief to the water resources of TRBD. Pressures from private wells of irrigation will drop from $80 \%$ to $60 \%$ of groundwater bodies' renewable resources. Moreover, it is notable that total water savings equal about $20 \%$ of Pinios' average annual runoff. Technical measures as well as irrigation scheduling and deficit irrigation are to be adopted in the short term . Changing the y early cotton crop to olives trees will $r$ equire further assessment for its implementation if necessary.

Future research might focus on the application of models towards im proved identification of the hydrological cycle components in the region alongside with seasonal $\mathrm{v}$ ariation of water demand 


\section{Appendix}

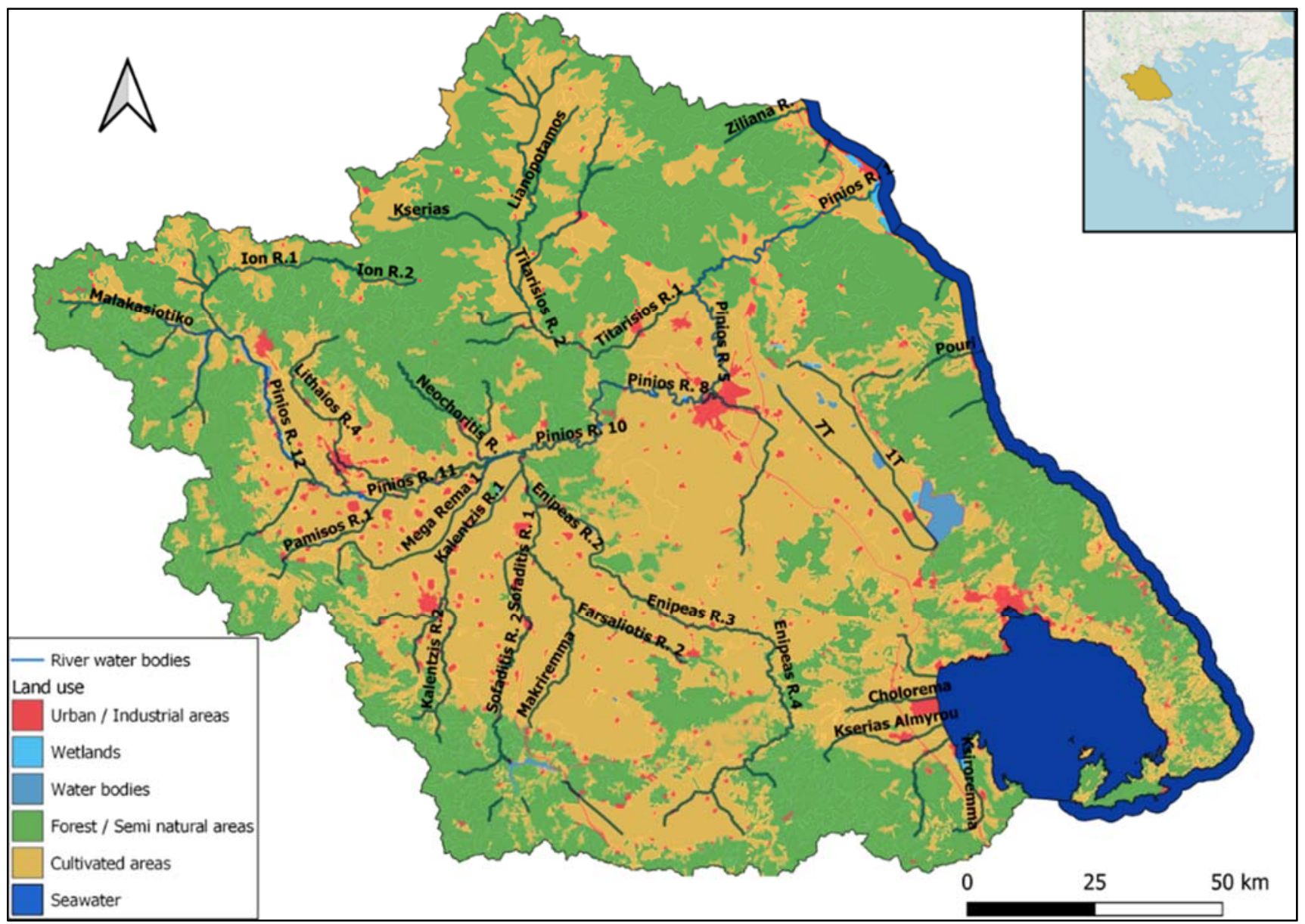

Figure 1, Land cover and river water bodies map of TRBD

\section{References:}

[1] 1st Revision RBDMP of Thessaly. (2017, December 29). Greek Government Gazette. (in Greek)

[2] Decentralized Administration of Thessaly and Central Greece. (2019). Consultation of the 2nd RBDMP of Thessaly. (in Greek)

[3] Loukas, A., Vasiliades, L., \& Tzabiras, J. (2007). Evaluation of Clim ate Change on Drought Impulses in Thessaly , Greece. European Water, 1718, 17-28.

[4] EEA. (2019). Development of the water exploitation index plus (WEI+). https://www.eea.europa.eu/data-andmaps/daviz/water-exploitation-index-plus\#

[5] Kovats, R. S ., Valentini, R., M.Bouwer, L., Georgopoulou, E., Jacob, D., Marti n, E., Rounsevell, M., \& Soussana, J.-F. (2014) . Europe, Climate Change 2014: Impacts, Adaptation, and Vulnerability. Part B: Regional Aspects. Contribution of Working
Group II to the Fifth Assessment Report of the Intergovernmental Panel on Climate Change (pp. 1267-1326). Cambridge Uni versity Press.

[6] Teodosiu, C., Barjoveanu, G., \& Teleman, D. (2003). Sustainable water resources management 1 . River basin management and the EC water framework directive. Environmental Engineering and Management Journal, 2(4), 377-394.

[7] Pahl-Wostl, C., Tàbara, D., Bouwen, R., Craps, M., Dewulf, A., Mostert, E., Ridder, D., \& Taillieu, T. (2008). The importance of social learning and culture for sust ainable water management. Ecological Economics, 64(3), 484-495.

[8] Koech, R., \& Langat, P. (2018). Improving irrigation water use efficiency: A review of advances, challenges and opportunities in the Australian context. Water (Switzerland), 10(12).

[9] Dworak, T., Berglund, M., Corneliu s, L., 
Strosser, P., Roussard, J., Benoit, G., Kossida, M., \& Ism ini, K. (20 07). Final report EU Water saving potential ( Part 1 - Report ). In Ecologic, Institute for International and European Environmental Policy (Issue July).

[10] Lecina, S., Isidoro, D., Playán, E., \& Aragüés, R. (2010). Irrigation modernization in Spain: Effects on water quantity and qua lity-a conceptual approach. International Journal of Water Resources Development, 26(2), 265282.

[11] Kanakoudis, V., \& Tsitsifli, S. (2010)

Results of an urban water distributio $n$ network performance evaluation attempt $\mathrm{i} n$ Greece. Urban Water Journal, 7(5), 267-285.

[12] BIO Intelligence Service. (2012) . Water saving potential in agriculture in Europe: findings from the existing studies and application to case studies Project description (Issue January).

[13] Brouwer, C., Prins, K., \& Heibloem, M. (1989). Irrigation Water Management: Irrigation Scheduling. FAO. http://www.fao.org/3/T7202E/t7202e00.htm\# Contents

[14] Berbel, J., Expósito, A., Gutiérrez-Martín, C., $\&$ Mateos, L. (2019). Effects of the Irrigation Modernization in Spai n 2002-2015. Water Resources Management, 33(5), 1835-1849.

[15] Cooley, H., Gleck, P., \& Wlkinson, R. (2014). Agricultural Water Conservation and Efficiency Potential in Cal ifornia. The Pisces Foundation, june, 1-12.

[16] Tal, A. (2016). Rethinking the sustain ability of Israel's irrigation practices in the Drylands. Water Research, 90, 387-394.

[17] Tognetti, R., Palladino, M., Minnocci, A., Delfine, S., \& Alvino, A. (2003). The response of sugar beet to dri $p$ and lowpressure sprinkler irrigation in southern Italy. Agricultural Water Management, 60(2), 135155.

[18] Cetin, O., \& Bilgel, L. (2002). Effects of different irrigation methods on shedding and yield of cotton. Agricultural Water Management, 54(1), 1-15.

[19] Marouelli, W. A., da Costa Lage, D. A., Gravina, C. S., Filho, M. M., \& de Souza, R. B. (2013). Sprinkler and drip irrigation in the organic tomato for single crops and when intercropped with coriander. Revista Ciencia Agronomica, 44(4), 825-833.

[20] Berbel, J., Martin-Ortega, J., \& M esa, P. (2011). A Cost-Effectiv eness Analysis of Water-Saving Measures for the Water
Framework Directive: $\mathrm{T}$ he Case of the Guadalquivir River Basin in Southern Spain. Water Resources Management, 25(2), 623640.

[21] Playán, E., \& Mateos, L. ( 2006). Modernization and optimization of irrigation systems to increase water productivity. Agricultural Water Management, 80(1-3 SPEC. ISS.), 100-116.

[22] Pereira, L. S., Paredes, P., Shol pankulov, E. D., Inchenkova, O. P., T eodoro, P. R., \& Horst, M. G. (2009) . Irrigation scheduling strategies for cotton to cope with water scarcity in the Fergana V alley, Central Asia. Agricultural Water Management, 96(5), 723735.

[23] W.L. Multer, Zhang, X., Wang, Y., Wam ple, R. L., Unruh, B. L., Stoll, M., Smithyman, R., Smith, M., Shock, C. C., Nautiy al, P. C., Boland, A.-M., Moutonnet, P., McCarthy, M. G., Li, Z., Loveys, B. R., Li, J., Kivumbi, D., Kirda, C., Jo shi, Y. C., ... Dayal, D. (2002). Deficit Irrigation Practices. Food and Agriculture Organization of the United Nations.

[24] Fereres, E., \& Soriano, M. A. (2007). Deficit irrigation for reducing agricultural water use. Journal of Experimental Botany, 58(2), 147159.

[25] Jaramillo, M. F., \& Re strepo, I. (2017) . Wastewater reuse in agr iculture: A r eview about its lim itations and b enefits. Sustainability (Switzerland), 9(10).

[26] Zhang, Y., \& Shen, Y. (2019). Wastewater irrigation: past, present, and future. Wiley Interdisciplinary Reviews: Water, 6(3), e1234.

[27] Heaton, R. D. (1981). Wastewater reclamation and reuse. GeoJournal, 5(5), 483-501.

[28] Pedrero, F., Camposeo, S., Pace, B., Cefola, M., \& Viv aldi, G. A. (2018). U se of reclaimed wastewater on fruit quality of nectarine in Southern Italy. Agricultural Water Management, 203(January), 186-192.

[29] Uzen, N., Cetin, O., \& Unlu, M. (2016) . Effects of d omestic wastewater treated by anaerobic stabilization on soil pollution, plant nutrition, and cotton crop yield. Environmental Monitoring and Assessment, 188(12).

[30] Kathijotes, N., \& Panay iotou, C. (2014) . Wastewater reuse for irrigation and seawater intrusion: Evaluation of salinity effects on soils in cyprus. Journal of Water Reuse and 
Desalination, 3(4), 392-401.

[31] González García, M., Fernández-López, C., Polesel, F., \& Trapp, S. (2019). Predicting the uptake of e merging organic contaminants in vegetables irrigated with treated wastewater Implications for food safety assessment. Environmental Research, 172(October 2018), 175-181.

[32] Christou, A., Agüera, A., Bay ona, J. M., Cytryn, E., Fotopoulos, V., Lambropoulou, D., Manaia, C. M., Michael, C., Revitt, M., Schröder, P., \& Fatta-Kassinos, D. (2017) . The potential im plications of reclaim ed wastewater reuse for $\mathrm{i}$ rrigation on the agricultural environment: The known $\mathrm{s}$ and unknowns of the fate of antibiotic $s$ and antibiotic resistant bacteria and resistance genes - A review. Water Research, 123, 448467.

[33] Mandouza, A. (2008). Analysis of the RBD of Thessaly under the context of the WFD using geodata. Aristotele University of Thessaloniki (in Greek).

[34] Tsiakalou, C. (200 8). The change of the agriculture sector in Larisa over the 1 ast 30 years: the case of water in the plain of Larisa. (in Greek)

[35] Rozos, D., Sideri, D., Loupasakis, C., \& Apostolidis, E. (2017) . Bulletin of the geological society of Gree ce. Bulletin of the Geological Society of Greece, 43(3), 18501857.

[36] Alamanos, A., Latinopoulos, D., Papaioannou, G., \& Mylopoulos, N. (2019). Integrated Hydro-Economic Modeling for Sustainable Water Resources Management in Data-Scarce Areas: The Case of Lake Karla Watershed in Greece. Water Resources
Management, 33(8), 2775-2790.

[37] Special Secreteriat for Water. (2018)

Wastewater Treatment Plants Monitoring Database.

http://astikalimata.ypeka.gr/Services/Pages/W tpViewApp.aspx\#

[38] Bakopoulou, S., Polyzos, S., \& Kungolos, A. (2010). Investigation of far mers' willingness to pay for using recycled water for irrigation in Thessaly region, Greece. Desalination, 250(1), 329-334.

[39] Lazaridou, D., Michailidis, A., \& Mattas, K. (2019). Evaluating the willingness to pay for using recycled water for irri gation. Sustainability (Switzerland), 11(19), 1-8.

[40] Hellenic Statistical Authority. (2017). Areas and production/ 2017. (in Greek) https://www.statistics.gr/en/statistics//publication/SPG06/-

[41] Vagenas, I. (2002). Crops water consumption in the prefecture of Thessaly . University of Thessaly. (in Greek)

[42] Administration of agri culture economy. (2018). Proper use of irrigation water. (in Greek)

[43] Michas, S., \& Gkiokas, A. (2012). Recording of public networks in Thessaly and investigation of efficiency of irrigation water trasfering. (in Greek)

[44] Supporting document \#8, 1st RBDMP of Thessaly. (2014). (in Greek)

[45] OPEKEPE. (2020). International Cotton Price. https://www.opekepe.gr/el/opekepe-iframeapps-gr/opekepe-timi-vamvaki-gr

[46] Agro24. (2020). Evolution of olive oil prices.

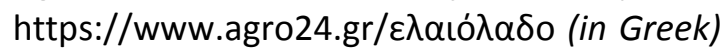

